\title{
Людмила Лучка
}

Дніпровський національний університет імені Олеся Гончара

\section{Книжкова спадщина Дніпропетровщини 20-30-х рр. XX ст.: історичний огляд та аналіз джерел}

\begin{abstract}
У статті висвітлено загальний стан національної книжкової видавничої справи 20-30-х рр. ХХ ст. Виявлено та проаналізовано цінні за змістом, поліграфічним оформленням, та часом друкування видання університетського книгозібрання. Досліджено історію та долю окремих примірників навчальної, наукової та художньої літератури. Увагу зосереджено на проблемах книговидавничого процесу в Україні, зокрема книг соціально-економічного, сільськогосподарського та технічного змісту. За джерелами проаналізовано діяльність відомих українських видавництв цього періоду та подано бібліографічний огляд репертуару видань. Серед книжкової продукції України значний відсоток належав академічній літературі, зокрема працям вчених різних галузей знань. Визначено роль та місце, яке посідали видавництва обласного рівня. Вагомим внеском у розвиток українського видавничого простору є література, присвячена Першій світовій війні. Створено загальну картину підготовки та друкування творів української художньої літератури, науково-популярних видань з різних галузей знань. Увага видавництв приділялась підготовці підручників для сільських шкіл. Окремим напрямком було створення популярних серед населення серійних видань. Цінними за змістом є львівські часописи, вісники $з$ історії та географії українських земель. Надано матеріали про цензурні утиски та вилучення творів діячів української науки, літератури, мистецтва. Виявлено та опрацьовано певну кількість краєзнавчих видань, що належать до національної книжкової спадщини, зокрема Д.І. Яворницького, І.І. Огієнка, Л.В. Писаржевського тощо. Під час наукової розвідки авторка намагалась висвітлити невідомі та забуті сторінки книгодрукування України, які пов’язані з розвитком та гальмуванням соціально- економічних і політичних процесів.
\end{abstract}

Ключові слова: книжкова спадщчина, бібліотечні колекиї̈, історія видавничої справи Украӥни, Дніпропетровщина, 20-30-і роки ХХ сm

\section{Lyudmila Luchka}

Oles Honchar Dnipro National University

\section{Book heritage of Dnipropetrovsk region of the 20s-30s of the 20th century: historical review and analysis of sources}

The article deals with general state of the national book publishing business of the $20 \mathrm{~s}-30 \mathrm{~s}$ of the 20th century. The author reveals and analyses the publications of the university book collection valuable in terms of content, design, and time of printing. The history and destiny of some books of educational, scientific and fiction literature are researched. The author's attention is focused on the problems of book publishing process in Ukraine, in particular books of social, economic, agricultural and technical content. The activity of well-known Ukrainian publishing houses of this period is analysed and a bibliographic review of the repertoire of the publications is given. The author notes a significant percentage of academic literature among Ukrainian book production, in particular the works of scientists in various fields of knowledge.

The role and place of publishing houses of the regional level are determined. The literature devoted to the World War I is an important contribution to the development of the Ukrainian publishing space. General picture of preparation and printing of works of Ukrainian fiction literature and popular science editions from various branches of knowledge is created. The attention of publishing houses was paid to the preparation of textbooks for rural schools. the creation of popular serial publications was a special feature. Lviv magazines, bulletins on the history and 
geography of Ukrainian lands are valuable in terms of content. Materials on censorship oppression and seizure of books on Ukrainian science, literature and art are provided. A number of local history publications related to the national book heritage are revealed and analysed, in particular by D.I. Yavornitsky, I.I. Ohienko, L.V. Pisarzhevsky and others. During the scientific research, the author tries to highlight the unknown and forgotten pages of book printing in Ukraine, which are related to development and inhibition of social, economic and political processes.

Keywords: book heritage, library collections, history of publishing in Ukraine, Dnipropetrovsk region, the 20 s-30s of the 20th century

\section{Постановка проблеми}

нига та видавнича справа
Катеринославщини-Дніпропетро-
вщини $\quad$ становить національної культурної спадщини, поперше, і по-друге, у відтворенні цілісної картини розвитку культурного потенціалу губернії.

\section{Аналіз публікацій}

Книгознавча тематика привертає увагу вітчизняних дослідників, про що свідчать наукові праці Г. І. Ковальчук , В. П. Ляхоцького, М. С. Тимошика, О. В. Яковлєва. Актуальність даного дослідження полягає у висвітленні процесу історичного розвитку української книги у 20-30x рр. $\mathrm{XX}$ ст. за фондами наукової бібліотеки ДНУ імені Олеся Гончара.

Мета дослідження полягає у виявленні та аналізі книжкових колекцій та окремих примірників, які вийшли друком в українських видавництвах у 20-30 pp. ХХ ст. Вибір теми $є$ підтвердженням того факту, що бібліотеки посідають провідне місце серед центрів збереження української спадщини. Книга як продукт видавничої галузі визначає духовний, культурний та інтелектуальний рівень суспільства на кожному історичному етапі його розвитку. Книги є джерелами інформації, що впливають на свідомість людини. Розвиток національної книги залежитьвідпроцесудержавотвореннякраїни та сприяє підвищенню загальнокультурного рівня населення. Історично склалося, що книгу розглядають як мистецький витвір i як предмет матеріального виробництва (Ковальчук, 2015).

\section{Виклад матеріалу}

У період 20-х pp. XX ст. потреба відродити економіку була неможливою без освіти та культури, а отже і без книги. Крім того, друковане слово було важливим ідеологічним засобом у процесі виховання та освіти українського населення. У 1920-ті роки українське книговидання розвивалося в складних умовах. Це був період руйнування попередньої системи: закриття діючих видавництв та книгарень, їх націоналізація та кооперація. За тематикою книжкове зібрання України 1920-1930 рр. було багатогалузевим, представлено усіма напрямками народного господарства, освіти і культури. За видами літератури поділялося на навчальну, наукову, науково-популярну, дитячу, художню.

Процес українізації відбувався повільно, мали місце недоліки: тяжке матеріальне становище гальмувало процес якісного та повного задоволення культурних потреб українського читача. Ситуацію ускладнювали такі чинники: нестача паперу, фарб, електрики, недостатне фінансування, зруйнована технічна база. У 19221923 рр. в Україні діяло 49 видавництв, у Катеринославській губернії - 6. Зростання накладів української книги та підвищення попиту відбувалося у 1923-1928 рр. за часів керівництва освітою О. Я. Шумського. Українська книга соціально-економічного, сільськогосподарського та технічного змісту відзначалася зростанням. Важливою була соціальна орієнтація друкованої продукції, а саме зазначення соціальних верств, читацькі потреби яких вона повинна задовольняти (Яковлєв, 2009, с. 359).

Найбільшими в Україні стали Державне видавництво України (ДВУ), яке спочатку мало назву Всеукраїнське державне видавництво, «Пролетарий», «Книгоспілка», «Український робітник». Протягом дослідженого періоду ДВУ залишалося універсальним і значним. Кожне видавництво повинно було чітко визначити характер своєї друкованої продукції і коло читачів. Зазначимо, що суспільно-політична література складала близько половини 
книжкової продукції. На думку українського видавця, катеринославського книгаря Д. Лисиченка (1930), у 20-х рр. XX ст. «книжка значно відрізняється від попередніх видань як своїм художнім виконанням, так і сама 3 себе: замість колишніх брошурок, метеликів, переважно друкують грубу книжку» (с. 68).

У 1925-1932 рр. зростають наклади української художньої літератури, наукової і літературних часописів. За цей період Видавництво Народного комітету освіти підготувало 70 книг. Всі видання були ілюстрованими i мали кольорові обкладинки, які викликали підвищений інтерес та читацький попит. У 1923 р. ДВУ провело конкурс на кращий буквар для сільської школи. Перевидавались переважно старі підручники, видання нових авторів з'являлися рідко. Значну роль у підготовці підручників для вищої школи відігравали вчені-фахівці різних галузей знань. Певний відсоток складали законодавчі документи, наприклад, «Українізація радянських установ: декрети, інструкції і матеріали. Харків, 1926» (Книга, 1964, с. 232).

У 1930 р. після реорганізації було створено Державне видавниче об'єднання України (ДВОУ), яке проіснувало до 1934 p. Окремі напрямки видавничої продукції ДВОУ складали підручники, словникові видання, художня література. Серед авторів навчальної літератури варто зазначити $Є$. К. Тимченко «Курс історії українського язика. Ч. I. К., Х., 1930»; А. С. Гутт «Курс гірничої геометрії. Ч. I. Х., Харків-Дніпропетровськ, 1931»; М. П. Беляєв «Курс вищої математики. Ч. І. Дніпропетровськ, 1928». Привертають увагу цінні за змістом видання: Д. I. Яворницький «Дніпрові пороги. Х., 1928»; В. К. Чапля (Чапленко Василь український письменник, мовознавець, місцевий діяч) «Сонет в українській поезії. Х., Одеса, 1930».; невеликий за обсягом твір українського історика Д. І. Багалія «Т. Г. Шевченко-поет пригноблених мас. Х., 1931». Серед словників є відомим «Практичний російсько-український словник. К., 1923», до якого увійшли правописні правила, складені Г. К. Голоскевичем (українським мовознавцем, громадським діячем, членом УЦР, автором найповнішого орфографічного словника української мови, репресованим). Видавнича діяльність об'єднання представлена творами українських письменників Г. Ф. Квітки-Основ'яненка (1928р.), Г. В. Михайличенка (1929р.) тощо. Варто додати, що видання художньої літератури друкувалися у серії «Праці Інституту Т. Г. Шевченка» (сучасного Інституту літератури імені Т. Шевченка НАН України) (Книга, 1964, с. 224).

У 30-ті рр. ДВОУ відкривало галузеві філії у Харкові, Одесі, Катеринославі: «Держтехвидав», «Держсільськогоспвидав», «Український робітник», «Література i мистецтво», «На варті». В Україні 20-30-х pp. користувалася попитом література, що пропагувала передові форми ведення сільського господарства. Серед примірників галузевого видавництва цікавість викликають: «Сучасне зернове господарство України» (1929) та видання 1933 р. «Дніпровське будівництво і сільське господарство районів зрошення» за авторським колективом під головуванням професора М. Розова. Останнє цікаве матеріалами 3 будівництва Дніпрельстану та плануванням меліоративної системи на землях Низового Дніпра.

Серед примірників видавництва «На варті» увагу дослідників привертає невеличке за обсягом харківське видання 1932 р. (36 сторінок) Г. Крисіна «Експедиція на Перекоп року 1931», до якого вміщено 30 ілюстрацій i мапу боїв за Перекоп. Назва та текст до ілюстрацій підготовлено двома мовами: українською та англійською. Інтерес дослідників викликає книга Б. М. Лізова «Шляхами інтервенцій. Харків, 1932» першою частиною під назвою «Інтервенції на Україні» та печаткою на титульному аркуші 3 текстом «sekretiert секретно не видається».

У 30-х pр. ХХ ст. виходили 3 друку ілюстровані твори класиків української художньої літератури, серед яких слід звернути увагу на книгу 1937 р. Державного літературного видавництва (Харків) «Вергілієва Енеїда» I. П. Котляревського. Це видання за художнім оформленням та форматом $\epsilon$ видатним явищем: великий формат, оправа зроблена з української плахти (барвисте полотнище, частина українського жіночого одягу). Книга має гравюри, заставки, багатокольорові наклейки, зроблені українським художником, графіком, 
живописцем М. Г. Дерегусом (Книга, 1964, c. 257).

Наступні видавництва, 3 книгами яких i сьогодні мають можливість працювати сучасники - «Рух», «Маса», «Книгоспілка», «Український робітник». Видавництво «Рух» (1921-1933) відоме творами українських письменників: В. К. Винниченка, Б. Д.Грінченка, І. Я. Франка, М. Ф. Чернявського. Осередок заснував «Бібліотечку української літератури для селянських $\mathrm{i}$ робітничих книгозбірень». У 1930 р. видавництво «Маса» (Київ) презентувало «Твори» М. В. Гоголя у перекладі С. В. Васильченка, літературне есе Б. Д. Антоненко-Давидовича «Землею українською».У 1927 роціприватневидавництво «Горно» (Київ) підготувало унікальну за змістом працю «Словник української мови. Т. 2» за упорядкуванням українського письменника Б. Д. Грінченка.

«Книгоспілка» як Всеукраїнське кооперативне книготорговельне i книговидавниче товариство була організована у 1923 р. Товариство видавало книги, брошури і періодику. «Книгоспілка» відповідала насамперед запитам сільського населення України. Крім того, видавнича продукція за тематикою мала широкий спектр: юридичні науки, медичні та педагогічні видання, шкільні підручники, літературознавчі твори. Окремий наголос робився на науково-популярні видання 3 різних галузей знань. Про високий рівень видавництва свідчить той факт, що заклад за накладами посідав друге місце в Україні та третє місце - за кількістю назв книг (Книга, 1964 , c. 224).

За постановою Державного науковометодологічного комітету Наркомосвіти УСРР від 1930 р. у харківському видавництві «Український робітник» друкували науковопопулярні книжки та твори українських письменників для дитячих бібліотек, а саме I. I. Малозьомов «Соціалістичне місто Велике Запоріжжя» (1933р.), М. П. Барабашов «Сонце». Певну кількість книг становили науково-популярні праці 3 питань природознавства (О.В.Палладін) та сільськогосподарська література з лікування хвороб.

Університетське зібрання зберігає літературу з історії Західної України. У 20 30-х pp. XX ст. в Галичині існувало близько
50 українських видавництв. Відомими осередками були Львів та Коломия [1, С. 411]. Грунтовними за змістом залишаються львівські видання: «Записки НТШ» (1930 р.) та «Літературно-науковий вісник» (1922 p.). У 1938 p. Український видавничий інститут у Львові підготував цінну історико-географічну працю «Географія українських i сумежних земель. Т. 1» за редакцією українського історика, географа, видавця, політичного діяча В. Кубійовича. Коломия відома видавництвом «Українська накладня», яке випускало у світ ілюстровані твори українських класиків та сучасних письменників, наприклад I. Я. Франко «Перехресні стежки» ([1922]). Примірник містить інформацію про три місця видання: Київ, Лейпциг, Коломия та передмову українського мовознавця, редактора Василя Верниволю (В. Сімовича).

У 1922 р. в Україні було створено Центральне управління в справах преси, яке 3 ідеологічних поглядів надсилало до видавництв та бібліотек документи 3 позначкою «таємно» 3 метою вилучення та заборони творів окремих авторів - діячів української науки, літератури, мистецтва. Так, у 1935 р. перелік заборонених авторів був великим (Б. Д. Антоненко-Давидович, М. Я. Олійник, В. П. Підмогильний, М. К. Вороний, Кость Гордієнко, Г. Д. Епік, М. Г. Куліш та ін.). Діяла заборона згадувати імена В. К. Винниченка, Д. І. Донцова, C. О. Єфремова, В. М. Кубійовича, Б. С. Лепкого, I. I. Огієнка, Миколи Хвильового (Ісаєвич, 2002, с. 409-410; Тимошик, 2003, с. 339). Підтвердженням $\epsilon$ книги, що збереглися до нашого часу i містять важливу інформацію. «Поезії» П. О. Куліша 1930-х рр., що побачили світ у видавництві «Книгоспілки», постраждали від цензури: повністю вирізано 59 аркушів передмови. Можна припустити, що іiі автор - Микола Зеров, український поет, критик, якого було звинувачено у керівництві терористичними націоналістичними організаціями, репресований. Із довідкової літератури відомо, що він був автором передмов багатьох видань «Книгоспілки».

Серед книжкової продукції України значний відсоток належав науковій літературі, зокрема виданням Академії наук УРСР. У 1925 р. заклад підготував 35 книг 
різногалузевого змісту. Збережені до нашого часу залишаються праці вчених: академіка Є. О. Патона, мовознавців Л. А. Булаховського та А. Є. Кримського, математика М. О. Граве, хіміка Л. В. Писаржевського, геолога П. А. Тутковського, істориків М. П. Василенка, О. I. Барановича, В. П. Бузескула. У 1928 р. ВУАН підготувала «Науково-публіцистичні i полемічні писання» М. I. Костомарова за редакцією М. С. Грушевського, виданих у Державному видавництві України. Академічні видання молодої країни містили назви двома мовами: українською та німецькою (Книга, 1964, с. 233).

Цікавою за оформленням $\epsilon$ праця українського вченого-географа, уродженця селища Царичанки Катеринославської губернії, академіка К. Г. Воблого «Економічна географія України: підручник для шкіл. Київ, 1922». Видання містить дві кольорові мапи: «Мапу земель, де живуть українці» 3 кресленням члена географічних комісій П. Тимошока та «Мапу розселення українців».

До складу української національної книжкової спадщини входять регіональні видання. Певний комплекс видань складають загальні історико-географічні праці, присвячені демографічним та статистичним показникам Катеринославщини («Местный бюджет Екатеринославской губернии на 1922/23 г.» (1923 р.), «Екатеринослав: настольная книга на 1923/24 год» (1924 р.), «Описание населенных мест Екатеринославской губернии на 1-е января 1925 г.» (1925р.), «Всесоюзная перепись населения 1926 года. Т. XII: УССР» (1929 р.).

Бібліотека зберігає видавничу продукцію Дніпропетровського інституту народної освіти (ДІНО), зокрема наукові збірники («Записки. Т. 1, 2» (1927-1928 рр.), «Наукові записки. Т. 1» (1929 р.), «Питання та замітки» $(1927$ р.)) та окремі праці викладачів Л. В. Писаржевського, І. Ю. Огієвецького, О. М. Динника тощо. У 20-х роках XX ст. вийшли з друку твори відомого українського історика, етнографа Д. І. Яворницького: «Словник української мови. Т. 1» (1920р.), «До історії Степової України» (1929 р.). 3 1923 року в «Українському видавництві у Катеринославі» починає своє життя праця українського вченого, громадського i церковного діяча I.I. Огієнка «Українська культура», що підготовлена шляхом фотодрукування (Ляхоцький, 2000, с. 69; Огієнко, 2007, с. 6).

Окремий комплекс видань визначеного хронологічного періоду складає література, присвячена Першій світовій війні 19141918 pр. У бібліографічному покажчику «Перша світова війна. Ч. 1.», підготовленому науковою бібліотекою ДНУ імені Олеся Гончара у 2017 р., надано інформацію про понад 100 збережених примірників за даною тематикою. 31925 року Воєнно-історична комісія з метою вивчення воєнного досвіду започаткувалапроект «Военно-исторической библиотеки». Цінними є 15 випусків у вигляді брошур обсягом 1-4 друкованих листів та окремих монографій, присвячених бойовим діям, воєнним операціям та історичним подіям Першої світової війни.

Виявлена література видавалася $\mathrm{y}$ Державному воєнному видавництві (Москва). Ії умовно можна поділити за двома напрямками: українсько- російські видання та перекладацька література (спогади, мемуари, щоденники учасників подій). Переклади здійснено з англійської, французької та німецької мов. Під час дослідження виявлено, що авторами видань були французькі воєначальники, дипломати, політики, британські та американські державні діячі, воєнні історики та розвідники. Варто звернути увагу на окремі видання, присвячені Україні: київське видання 1936 року «Сражение на Марне в 1914 г.: по немецким материалам» містить 14 схем; видання 1923 року «Стратегический очерк войны 1914-1918 гг. Ч. 2» висвітлює воєнні дії та операції, що відбувалися на території Українських Карпат (38 схем). Цікавою $є$ ювілейна харківська брошура «Воспоминание фронтовика» Я. Кальницького, підготовлена до 10-ї річниці війни (Перша світова, 2017, с. 29).

\section{Висновки.}

Під час дослідження була відтворена цілісна картина розвитку видавничої справи України у складні часи 20-30-х років XX ст. За тематикою книжковий репертуар України був багатогалузевим, широкої читацької спрямованості, представлений усіма напрямками народного господарства, освіти та культури. Кожне видавництво чітко визначало характер друкованої продукції i коло читачів (різні верстви 
населення). У зв'язку 3 підвищеним читацьким попитом зростали наклади художньої літератури, яку використовували 3 метою самоосвіти. Важливий напрямок видавничої галузі складали підручники, навчальні посібники, словникові видання. Аналіз виявлених видань допоміг створити значне коло персоналій та розширити реєстр української біографістики. Вагомий відсоток складали видання Академії наук УРСР, а саме грунтовні праці перших академіків України, підготовлені двома мовами. Як джерело, цінними за змістом є видання 3 історії Першої світової війни 1914-1918 рр. (спогади, мемуари, щоденники). Університетська книгозбірня зберігає київські, харківські примірники, унікальність яких полягає у змісті, авторстві та друкарському оформленні. Корисними за інформацієює львівські часописита вісники, монографії відомих українських істориків, географів, політичних діячів. Виявлені окремі примірники різних видавництв та галузей знань дозволили сформувати уявлення про стан та зміст культурного потенціалу Дніпропетровської області. Аналіз видань за певними ознаками (мова, структура, зміст, друкарське оформлення, цензура) допомагає визначити роль та місце університетських бібліотек у процесах збереження національної книжкової спадщини та створення загальнодержавного реєстру пам'яток. Процес книговидання 20-30-х рр. ХХ ст. свідчить про потребу та шану до української книжки, їі проблеми, педагогічні аспекти. Незважаючи на складні політичні умови, ідеологічний контроль та цензурні утиски, українська книга 20-30 рр. зробила вагомий крок подальшого розвитку видавничої справи України.

\section{REFERENCES}

Isaievych, Ya. (2002). Ukrainske knyhovydannia: vytoky, rozvytok, problemy [Ukrainian book publishing: origins, development, problems] Lviv: Instytut ukrainoznavstva im. I. Krypiakevycha NAN Ukrainy [in Ukrainian].

Knyha i drukarstvo na Ukraini [ Books and printing in Ukraine]. (1964). Kyiv: Naukova dumka [in Ukrainian].

Kovalchuk, H. I. (2015). Ukrainskyi naukovyi instytut knyhoznavstva (1922-1936) [Ukrainian Scientific Institute of Bibliology (1922-1936)]. Kyiv: Akademperiodyka [in Ukrainian].

Lysychenko, D. (1930). Korotkyi ohliad ukrainskoi vydavnychoi diialnosti, presy ta knyhotorhivli na kolyshnii Katerynoslavshchyni [A brief overview of Ukrainian publishing, press and book trade in the former Ekaterinoslav region]. Bibliol. Visti, 2, 57-69 [in Ukrainian].

Liakhotskyi, V. (2000). Tilky knyzhka prynese voliu ukrainskomu narodovi...[Only a book will bring freedom to the Ukrainian people]. Kyiv: Vydavnytstvo imeni Oleny Telihy [in Ukrainian].

Ohiienko, I. (2007). Istoriia ukrainskoho drukarstva [History of Ukrainian printing]. Kyiv: Nasha kultura i nauka [in Ukrainian].

Persha svitova viina: anotov. bibliohr. pokazhchyk [World War I: annotations. bibliogr. index]. (2017). (Vol. 1). Dnipro:

DNU [in Ukrainian].

Tymoshyk, M. (2003). Istoriia vydavnychoi spravy [History of publishing]. Kyiv: Nasha kultura i nauka [in Ukrainian]. Iakovliev, O. V. (2009). Osoblyvosti rozvytku knyhovydavnychoi spravy v Ukraini v 20-kh rokakh XX st. [Features of the development of book publishing in Ukraine in the 20s of the twentieth century]. Rukopysna ta knyzhkova spadshchyna Ukrainy, 355-361. Kyiv: NBUV [in Ukrainian].

Luchka Lyudmila

Ph.D., https://orcid.org/0000-0003-1656-0945, Luchka64@i.ua

Стаття надійшла / Article arrived: 04.02.2021

Схвалено до друку / Accepted: 16.03.2021 